\title{
Analysis of Surface Roughness Value When Drilling Magnesiumaz31 Using Taghuci Method
}

\author{
Gusri Akhyar Ibrahim ${ }^{1 *}$, Arinal Hamni ${ }^{1}$, Sri Maria Puji Lestari ${ }^{2}$
}

\begin{abstract}
Magnesium alloy is one of super alloys material which wide used in manufacturing of automotive, biomedic, sport and electronic components. It was due to very light and resistent to corrosion. Surface roughness value has an important role to estabilish the quality of components. To produce a good surface roughness of machined surface, one of the important thing depends on the friction between the cutting tool and workpiece material when cutting process occurred. The aim of this paper is to analyse the surface roughness values of machined surface when drilling of magnesium alloy AZ31 using design of experiment of Taguchi Method. The experimental trials took place at cutting rotation of 635,970 and $1420 \mathrm{rpm}$, feed rate of $0.10,0.18$ and $0.24 \mathrm{~mm} / \mathrm{rev}$, diameter tool of 10,12 and $14 \mathrm{~mm}$. The cutting of magnesium alloy was done by using a convensional drilling machine with TCA 35Erlo. Analysis of variance on the data of surface roughness value was done to get which factor is the most significant. The result shows that the feed rate is the most significant factor that contributed on the surface rougness value of machined surface. The minimum surface roughness value was attained at cutting rotation of $970 \mathrm{rpm}$, feed rate of $0.10 \mathrm{~mm} / \mathrm{rev}$ and diameter of tool of $14 \mathrm{~mm}$. Therefore, it can be stated that selecting the low feed rate factor produced low surface roughness value. Another hand, using high cutting rotation resulted low surface roughness value.
\end{abstract}

Keywords — drilling, surface roughness, magnesiun AZ31,Taguchi Method

\section{INTRODUCTION}

$\mathbf{P}$ URE magnesium and magnesium alloy have been known as materials that have characteristic such as very light, easy to burned and very easy to react to others materials. Pure magnesium does not has enough strength, therefore magnesium is very good when blended with other elements toget better characteristics. One is the important attribute of magnesium alloy is strong at high weight ratio $[1,2]$. Pure magnesium produced by casting, forming and machining.

${ }^{1}$ Department of Mechanical Engineering, University of Lampung, Gedung H, Lt 2, Jalan Prof. Soemantri Brojonegoro No. 1, Bandar Lampung, Indonesia.

${ }^{2}$ Department of Mechanical Engineering University of Malahayati, Jalan Pramuka No. 27, Kemiling Permai, Bandar Lampung.

"Correspondence to T. aAuthor, email : gusri.akhyar@eng.unila.ac.id. Tel.:+62-721-704947; fax.:+62-721-704948.
One of important produced methods is machining to make a precision component. The aim of machining of magnesium alloy is to achieve surface quality of component.

One of dominant magnesium characteristics is easy to react with other materials (pyrophepric), so that high risksflame/burn. In spite of products from magnesium have a risk as long as machining process, but manufactured process can be controlled [1].

In field of biomedicand health, using material magnesium as replacing bone has some advantages. The advantages are such as mechanical properties similar to bone and good biocompatible with the body. In the body, magnesium alloys degrade naturally for certain time priode. In the case of bone joint use pin which is manufactured from magnesium alloy, not need second surgery to take away the implant from the body. In addition to using magnesium alloy is more economical compare to others materials, such as titanium and stainless steel [2].

Aplications of magnesium alloys in industrial manufactures purpose to get an unique characteristics. Magnesium alloys applied as coating on surface of ferroes materials and steels to protect them from corrosion. Its application on electronic components due to magnesium alloys has good conductivity. In the industrial aerospace, application of magnesium alloy aims to reduce weight and increase saving energy [2,3].

Similar to industrial aerospace field, application magnesium alloys in the automotive industries to get very light components, resistant to corrosion and interested performance (good accessories). One of application of magnesium alloys is an engine block, which has light weight, conductive material, resistant when operate at high temperature and high strength [3].

Beside of some good characteristics of magnesium alloys, surface roughness value is an important thing as represent the quality of product. The surface roughness value has a significant role in machining process due to influence on coefficient friction between the cutting tool and workpiece material $[4,5]$.

Some previus researchers were done experiment to reduce surface roughness value by optimizing cutting parameters. Faruk and Bunyamin [6] identified the effect of tool diameter and feed rate on surface roughness value. The results showed that the surface roughness value tend to increased when cutting at low tool diameter. It was caused by 
high cutting speed generated smooth machined surface. Whereas selecting high feed rate and low cutting speed produced the rought machined surface. The highest surface roughness was as effect of the feed rate dominantly.

Other experimental result stated that the surface roughness value influenced by cutting parameters, mainly by feed rate [7]. Cuting by using high feed rate produced high surface roughness value. Even, the feed rate was a significant factor which influenced the surface roughness value.

Taguchi Method is a design experimental method that widely used in industrial manufacture. This method purposed to optimize on machined parameters. Surface roughness value is an indicator to achieve good machined surface quality and the lowest surface roughness is the main goal in optimizing machined parameter. Therefore, this experiment aims to apply Taguchi Method to determine optimal machining parameters which produces the best surface roughness value. Quantitative analysis is done to get significant effect for eah parameter.

\section{EXPERIMENTAL METHOD}

Magnesium alloy used in this experiment is magnesium alloy AZ31 with chemical composition $3 \%$ of aluminium and $1 \%$ of zinc. Magnesium alloy was drilled by using drilling machine with merk of TCA-35 Erlo. Drilling process was done in dry machining or without using coolant or lubricant. Surface roughness of machined surface was measured by using the surface roughness tester. The cutting tool used twiss drill type with material of high speed steel.

Machining of magnesium alloy was done by drilling maching are at rotation speed (n) of $635 \mathrm{rpm}, 970 \mathrm{rpm}$ and $1420 \mathrm{rpm}$; feed rate (f) of $0.10 \mathrm{~mm} / \mathrm{rev}, 0.18 \mathrm{~mm} / \mathrm{rev}$ and 0.24 $\mathrm{mm} / \mathrm{rev}$; and diameter of twist drill (d) of $10 \mathrm{~mm}, 12 \mathrm{~mm}$ and $14 \mathrm{~mm}$. Taguchi Method recommended that if consist of three factors and three levels, orthogonal array with L9 used. Detailly, arthogonal array with L9 and its combination as shown in Tabel 1 and Tabel 2.

Table1. Factors and levels for each machining parameters

\begin{tabular}{lccc}
\hline \multirow{1}{*}{ Factors } & \multicolumn{3}{c}{ Level } \\
\cline { 2 - 4 } & 1 & 2 & 3 \\
\hline Diameter of tool (mm) & 10 & 12 & 14 \\
Rotation speed (rpm) & 635 & 970 & 1420 \\
Feed rate (mm/rev) & 0.10 & 0.18 & 0.24 \\
\hline
\end{tabular}

Table 2. Design matric for orthogonal array L9

\begin{tabular}{cccc}
\hline & \multicolumn{3}{c}{ Machining Parameters } \\
\cline { 2 - 4 } No & $\begin{array}{c}\text { Diameter of } \\
\text { twiss drill }\end{array}$ & Rotation Speed & Feed Rate \\
\hline 1 & 1 & 1 & 1 \\
2 & 1 & 2 & 2 \\
3 & 1 & 3 & 3 \\
4 & 2 & 1 & 2 \\
5 & 2 & 2 & 3 \\
6 & 2 & 3 & 1 \\
7 & 3 & 1 & 3 \\
8 & 3 & 2 & 2 \\
9 & 3 & 3 & 1 \\
\hline
\end{tabular}

Drilling processes were done nine times with different setting parameters. Surface roughness values were recorded after drilling by using surface roughness tester. Data of surface roughness were analyzed quantitatively by using minitab software to get imformation about variance analysis, which parameter contribution significantly, and correlation of graphic for each parameter.

\section{RESULTS AND DISCUSSIONS}

Table 3 shows the surface roughness values of machined surface that machined by using drilling at dry cutting condition. The surface roughness values are range in $0.99-$ $1.53 \mu \mathrm{m}$. The lowest surface roughness value is $0.99 \mu \mathrm{m}$, which isreached at machining condition with diameter tool of $14 \mathrm{~mm}$, feed rate of 0.10 and rotation speed of 970 $\mathrm{rpm}$. Althought the surface rougness values are fluctuation for every combination of setting parameters, but the range of fluctuation is not more than of $50 \%$.

Table 3. Experimental results data

\begin{tabular}{ccccc}
\hline \multicolumn{5}{c}{ Machining Parameters } \\
\hline No & $\begin{array}{c}\text { Diameter of } \\
\text { tool }(\mathrm{mm})\end{array}$ & $\begin{array}{c}\text { Rotation } \\
\text { Speed }(\mathrm{rpm})\end{array}$ & $\begin{array}{c}\text { Feed Rate } \\
(\mathrm{mm} / \mathrm{rev})\end{array}$ & $\begin{array}{c}\text { Surface } \\
\text { roughness } \\
(\mu \mathrm{m})\end{array}$ \\
\hline 1 & 10 & 635 & 0.1 & 1.29 \\
2 & 10 & 970 & 0.18 & 1.52 \\
3 & 10 & 1420 & 0.24 & 1.34 \\
4 & 12 & 635 & 0.18 & 1.43 \\
5 & 12 & 970 & 0.24 & 1.32 \\
6 & 12 & 1420 & 0.1 & 1.03 \\
7 & 14 & 635 & 0.24 & 1.38 \\
8 & 14 & 970 & 0.1 & 0.99 \\
9 & 14 & 1420 & 0.18 & 1.25 \\
\hline
\end{tabular}

Analysis of variance (ANOVA) for S/N ratio 
Analysis of variance (Anova) is used for get imformation about the effect on each parameter on response parameter (surface roughness). Table 4 shows analysis results of the surface roughness by using Minitab 14 software.

Value of each factor is as shown in columb $\mathrm{P}$ (significant value). Feed rate is the most significant factor which contributes on the surface roughness. The significant value of feed rate is 0.32 , in which this value is lower than other factors (diameter of tool is 0.094 and rotation speed of 0,115 ). Theoritically, the feed rate directly contributes on surface roughness of machined surface. If feed rate was increased, so surface roughness value also increases quadratically. As stated by previous researcher that for machining of superalloys material (including magnesium), the feed rate significant influenced on surface roughness value [8]. Selecting bigger feed rate contributed on profile of machined surface in term of feed mark and valley.

Tabel4. Analysis Of Variancefor $\mathrm{S} / \mathrm{N}$ ratioon the surface roughness

\begin{tabular}{lcccccc}
\hline & DF & Seq SS & Adj SS & Adj MS & F & P \\
\hline $\begin{array}{l}\text { Diameter } \\
\text { of tool } \\
(\mathrm{mm})\end{array}$ & 2 & 24.573 & 24.573 & 12.287 & 9.65 & 0.094 \\
$\begin{array}{l}\text { Rotation } \\
\text { speed } \\
\text { (rpm) }\end{array}$ & 2 & 19.512 & 19.512 & 0.9756 & 7.66 & 0.115 \\
$\begin{array}{l}\text { Feed Rate } \\
\text { (mm/rev) }\end{array}$ & 2 & 77.110 & 77.110 & 38.555 & 30.27 & 0.032 \\
$\begin{array}{l}\text { Residual } \\
\text { error }(\%)\end{array}$ & 2 & 0.2548 & 0.2548 & 0.1274 & & \\
Total & 8 & 123.743 & & & & \\
\hline
\end{tabular}

Table5. Response table for signal to noise ratio with characteristic of smaller is better

\begin{tabular}{cccc}
\hline Levels & Tool diameter $(\mathrm{mm})$ & $\begin{array}{c}\text { Tool speed } \\
(\mathrm{rpm})\end{array}$ & $\begin{array}{c}\text { Feed rate } \\
(\mathrm{m} / \mathrm{rev})\end{array}$ \\
\hline 1 & -2.7969 & -2.7054 & -0.7937 \\
2 & -1.9250 & -1.9870 & -2.8939 \\
3 & -1.5495 & -1.5790 & -2.5837 \\
Delta & 1.2474 & 1.1264 & 2.1002 \\
\hline Ranking & 2 & 3 & 1
\end{tabular}

Table 5 shows response values of $\mathrm{S} / \mathrm{N}$ ratio surface roughness each factor. It clearly that the feed rate is at rank 1 as factor which significantly contribute on the surface roughness, and followed by diameter of tool and tool speed. However, diameter of cutting tool gave a contribution but it is not signifincant. The contribution of tool diameter is $9,4 \%$. This value is bigger than contribution of rotation speed of cutting tool. Diameter of cutting tool has a direct correlation with cutting speed; because of the cutting speed depend on the diameter of tool.

The delta value of feed rate is 2.1002 as shown in Table 5 , in which bigger than others values. The range of minimum value and maximum value of $\mathrm{S} / \mathrm{N}$ ratio explains the effect of its factor. For factor feed rate, the response value between level 1 and level 2 is $2.1002(2.8939-0.7937)$. This value is bigger than the response value between level 2 and level 3. It is very possible due to the range value of feed rate between level1 and level 2 also bigger than the range between level 2 and level 3. In the experimental analysis, it's better to set range velues among level is constant.

Figure 1 shows main effect of signal to noise ratio ( $\mathrm{S} / \mathrm{N}$ ratio) for each factor on the surface roughness values. For diameter of the cutting tool at level 3 give more effect compare to others factors. Therefore, it can be stated that diameter of cutting tool with level of 3 produced the lowest surface roughness value (smoother). Such was this case, the tool speed at level 3 also give more contribution on the surface roughness of machine surface [9]. Contradiction with the diameter of tool that feed rate at level 1 gives more contribution on the surface roughness. Specially for the feed rate, it can be concluded that lower feed rate produced lower surface roughness values.

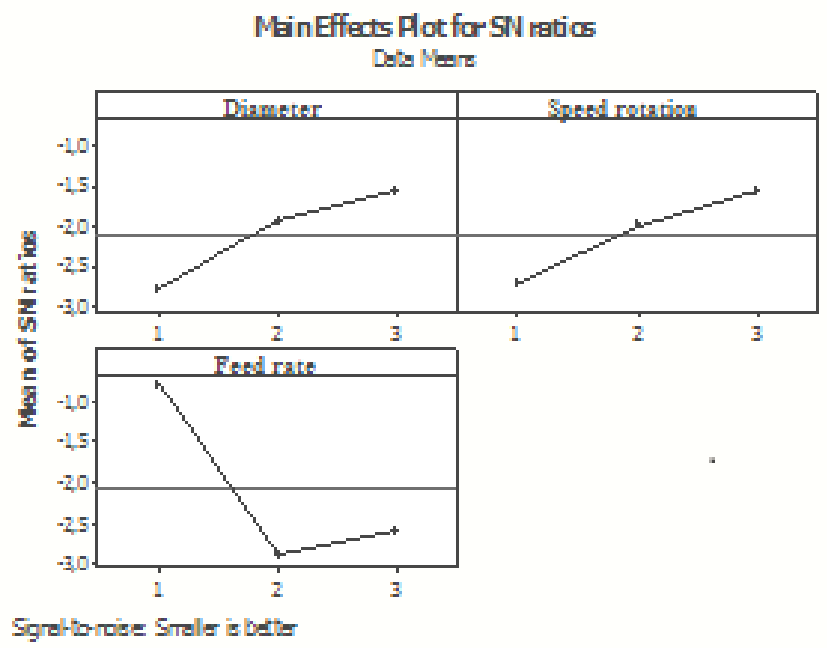

Fig.1. Main effect plot for $\mathrm{S} / \mathrm{N}$ ratio of surface roughness values

\section{IV.CONCLUSIONS}


From the analysis it can be concluded that Taghuci Method can be applied to analize the machining parameters when drilling magnesium AZ31, in which tool diameter of 14 $\mathrm{mm}$, rotation speed of $970 \mathrm{rpm}$ and feed rate of $0.10 \mathrm{~mm} / \mathrm{rev}$ is the best machining condition which produced the lowest surface roughness value.

1. Analisysof Varianonsignal to noise ratios shows that the feed rate is the significant factor which contribute of 0.032 $(3.2 \%)$.

2. The graph analysis and ANOVA for show the result that using cutting tool with diameter of $14 \mathrm{~mm}$, speed rotation of $1420 \mathrm{rpm}$, and feed rate of $0,10 \mathrm{~m} / \mathrm{rev}$ gave the most significant factor on surface roughness value

\section{ACKNOWLEDMENTS}

These authors acknowledge the financial support from Directorate General of Higher Education of Ministtry of Research and High Education of Indonesia. The acknowledments also for University of Lampung which facilitated the equipments to finish this experiment.

\section{REFERENCES}

[1] Suhairi, 2010, Pengaruh variable pemotongan terhadap kualitas permukaan produk dalammeningkatkan produktifitas, Jurnal Jurusan Teknik Mesin Politeknik Negeri Padang.

[2] Badeges, A. 2012, Analisis proses biodegradasi magnesium yang telahmelaui proses equal chanel angular pressing ecap dalam cairan fisiologis (Invitro), Universitas Indonesia.

[3] Bruni, C., Forcellese, A., Gabrielli, F., Simoncini, M. 2004, Effect of temperature strain rate and fibre orientation on the plasticflow behaviour and formability of AZ31magnesium alloy, Department of Mechanics, Università Politecnicadelle Marche, Via Brecce Bianche, Ancona 60131. Italy.

[4] Gusri, A.I. 2015, Analisa nilai kekasaran permukaan paduan magnesium AZ31 yang dibubut menggunakan pahat potong berputar, Proceeding Seminar Nasional Tahunan Teknik Mesin XIV (SNTTM XIV.

[5] Gusri, A. I., Suryadiwansa, H., Arinal, H. 2016, Surface roughness values of magnesiaum alloy AZ31 when turning by using rotary cutting tool, Insist, Vol.1, No. 1, pg. 54-59.

[6] Faruk, K. 2016, Effect of the tibn coating on ahss drill when drilling the mg alloy, Yildiz Technical University Istanbul Turki.
[7] Gusri, A. I. 2014, Identifikasi nilai kekasaran permukaan pada pemesinan paduan magnesium, Universitas Lampung

[8] Ibrahim,G.A., CheHaron, C.H., Ghani, J.A. 2010, Taguchi optimization method for surface roughness and material removal rate in turning of Ti-6Al-4V ELI, International Review of Mechanical Engineering, Vol. 4, No. 3, pp. 216-221.

[9] Gusri, A.I. 2011,Aplikasi metode Taguchi untuk mengindentifikasi kekasaran permukaan dalam pembubutan paduan titanium,Jurnal Teknik Mesin Indonesia, Vol. 6, No. 1, pp. 84-88 